\title{
Sporadic Thyroid Gland Micromedullary
} Carcinoma

National Cancer Institute

\section{Source}

National Cancer Institute. Sporadic Thyroid Gland Micromedullary Carcinoma. NCI

Thesaurus. Code C46103.

A sporadic thyroid gland medullary carcinoma measuring less than $10 \mathrm{~mm}$ in diameter. 